\title{
Discussion on 'Spectral analysis of aeromagnetic data for geothermal energy investigation of Ikogosi Warm Spring - Ekiti State, southwestern Nigeria'
}

\author{
Levi Ikechukwu Nwankwo
}

\section{Correspondence:}

levinwankwo@yahoo.com

Geophysics Research Group,

Department of Physics, University of

Ilorin, Ilorin 240003, Nigeria

\begin{abstract}
Background: The recent paper by Abraham et al. (2014) 'Spectral analysis of aeromagnetic data for geothermal energy investigation of Ikogosi Warm Spring - Ekiti State, southwestern Nigeria' applied spectral analysis in the interpretation of aeromagnetic data for estimation of curie-point depths using a data window of $55 \times 55 \mathrm{~km}$; however, the employment of such small window may not be consistent with derived curie-point depth results.

Discussion: Here, I would like to clarify and point out the possible errors in the paper.

Summary: It is suggested that the curie-point depth results be re-computed with appropriate window width. This would tremendously assist researchers in appropriate spectral calculation and curie-point depth investigations.
\end{abstract}

Keywords: Spectral analysis; Aeromagnetic; Geothermal; Data window; Curie-point depth

\section{Background}

Spectral analysis has been widely acknowledged as a robust method for automated depth estimations from magnetic anomaly data (Nabighian et al. 2005). The approach considers the anomaly to be caused by an ensemble of magnetic sources in order to determine their average depth. Spector and Grant (1970) showed that logarithmic radial-power spectra of gridded magnetic data contain constant-slope segments that can be interpreted as arising from statistical ensembles of sources, or equivalent source layers, at different depths. However, the areal extent of the subset of data analyzed (the window) limits the maximum depth being investigated. For a given horizon depth, there is an optimal window size that detects the horizon with the least noise and greatest stability. Window sizes are chosen to focus on different depths of investigation; small windows target shallow depths, as the shallow sources produce high-frequency anomalies, and larger windows target greater depths with deep-seated bodies (Archimedes Consulting 2013).

In a study of different spectral methods (including the centroid method adopted by Okubo et al. 1985 and Tanaka et al. 1999) of estimating the depth to the bottom of magnetic sources (also regarded as a proxy for an estimate of curie-point depth (CPD)), from magnetic anomaly data, Ravat et al. (2007) reiterated using data windows 
with sufficient width to ascertain that the response of the deepest magnetic layer is captured and by verifying the spectra and computing the depth estimates with the largest possible windows. There has been an agreement among researchers in the field that the dimension of the window analyzed may need to be, in some cases, up to ten times the depth to the bottom (Chiozzi et al. 2005; Ravat et al. 2007). Therefore, the purpose of this review is to clarify and point out the possible errors in the recent paper authored by Abraham et al. (2014) regarding data window. This would tremendously assist researchers in appropriate spectral calculation and CPD investigations.

\section{Discussion}

In the recent paper by Abraham et al. (2014) 'Spectral analysis of aeromagnetic data for geothermal energy investigation of Ikogosi Warm Spring - Ekiti State, southwestern Nigeria, 22 randomly selected blocks of dimension $55 \times 55 \mathrm{~km}$ (data window) were utilized for CPD evaluation using spectral centroid method. Consequently, they obtained CPD results ranging between 11.48 and $21.91 \mathrm{~km}$. However, bearing in mind the extent of deep-seated magnetic investigations such as CPD, the utilization of such a small window width may be a fundamental error in the application of spectral methods for aeromagnetic interpretation for geothermal explorations. The authors themselves admitted that the spectrum of a magnetic map only contains depth information to a depth of length $(L) / 2 \pi$, and if the source bodies have bases deeper than $L / 2 \pi$, they cannot be resolved by spectral analysis (Shuey et al. 1977; Salem et al. 2000).

Considering a data window of $55 \times 55 \mathrm{~km}$ used by Abraham et al. (2014), only depth information to a depth of $8.75 \mathrm{~km}$ could be satisfactorily resolved by spectral analysis. Consequently, the CPD values reported in the paper could likely be erroneous. The 55$\mathrm{km}$ dimension windows will neither be adequate to analyze 11.48- nor 21.91-km base depths as reported by Abraham et al. (2014). To obtain a reliable and accurate CPD result that is up to $21.91 \mathrm{~km}$ as reported in the paper, a data window not less than $138 \times$ $138 \mathrm{~km}$ must be utilized. Ravat et al. (2007) underscored the importance of computing the spectra and depths with large windows to ensure that the response of the deepest layer is properly captured. Nevertheless, this is not the case in the reviewed publication.

\section{Summary}

Accordingly, the estimated CPD values and ensuing geothermal gradients and heat flows by Abraham et al. (2014) could be erroneous. Therefore, it is recommended that the CPD results be re-computed with appropriate window width.

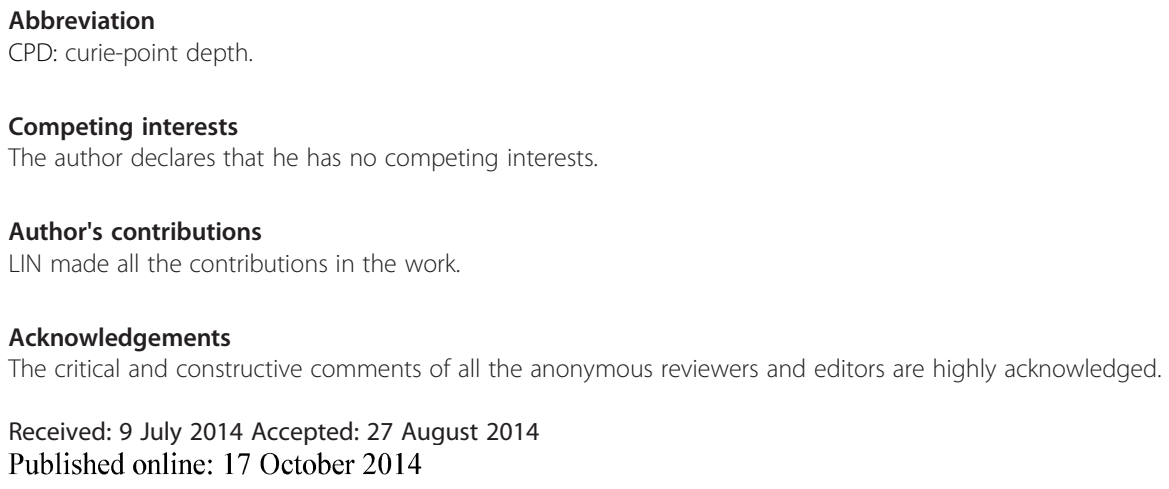


References

Abraham EM, Lawal KM, Ekwe AC, Alile O, Murana KA, Lawal AA (2014) Spectral analysis of aeromagnetic data for geothermal energy investigation of Ikogosi Warm Spring - Ekiti State, southwestern Nigeria. Geothermal Energy 2:6

Archimedes Consulting (2013) Mapping sub-salt and sub-basalt structures from magnetic and gravity data. http:/www. geoexpro.com/articles/2013/02/mapping-sub-salt-and-sub-basalt-structures-from-magnetic-and-gravity-data. Accessed 2 July 2014

Chiozzi P, Matsushima J, Okubo Y, Pasquale V, Verdoya M (2005) Curie-point depth from spectral analysis of magnetic data in central southern Europe. Phys Earth Planet Int 152:267-276

Nabighian MN, Grauch VJS, Hansen RO, LaFehr TR, Li Y, Peirce JW, Phillips JD, Ruder ME (2005) The historical development of the magnetic method in exploration. Geophysics 70(6):33-61

Okubo Y, Graf RJ, Hansent RO, Ogawa K, Tsu H (1985) Curie point depths of the island of Kyushu and surrounding areas, Japan. Geophysics 53:481-494

Ravat D, Pignatelli A, Nicolosi I, Chiappini M (2007) A study of spectral methods of estimating the depth to the bottom of magnetic sources from near-surface magnetic anomaly data. Geophys J Int 169:421-434

Salem A, Ushijima K, Elsiraft A, Mizunaga H (2000) Spectral analysis of aeromagnetic data for geothermal reconnaissance of Quseir area, northern Red Sea, Egypt. In: Proceedings of the world geothermal congress, Kyushu-Tohoku, 28 May-10 June 2000

Shuey RT, Schellinger DK, Tripp AC, Alley LB (1977) Curie depth determination from aeromagnetic spectra. Geophys J Roy Astr Soc 50:75-101

Spector A, Grant FS (1970) Statistical models for interpreting aeromagnetic data. Geophysics 35:293-302

Tanaka A, Okubo Y, Matsubayashi O (1999) Curie point depth based on spectrum analysis of the magnetic anomaly data in East and Southeast Asia. Tectonophysics 306:461-470

doi:10.1186/s40517-014-0011-3

Cite this article as: Nwankwo: Discussion on 'Spectral analysis of aeromagnetic data for geothermal energy investigation of Ikogosi Warm Spring - Ekiti State, southwestern Nigeria'. Geothermal Energy 2014 2:11.

\section{Submit your manuscript to a SpringerOpen ${ }^{\circ}$} journal and benefit from:

- Convenient online submission

Rigorous peer review

- Immediate publication on acceptance

- Open access: articles freely available online

- High visibility within the field

Retaining the copyright to your article 